\title{
Assessment of groundwater pollution risk potential using DRASTIC Model in Yogyakarta City, Indonesia
}

\author{
Syampadzi Nurroh*, Totok Gunawan, and Andri Kurniawan \\ Faculty of Geography, Universitas Gadjah Mada, Yogyakarta, Indonesia
}

\begin{abstract}
Assessment of groundwater pollution risk is purposed to be of particular value for environmental management programs development, this research estimated and calculated of groundwater pollution risk potential in Yogyakarta City using DRASTIC Model, DRASTIC parameters developed as Depth to water (D), net Recharge (R), Aquifer media (A), Soil media (S), Topography (T), Impact of vadose zone (I), and Hydraulic conductivity $(\mathrm{C})$, the weights and ratings assigned in this research were similar to the typical ratings suggested in the original Methode. The result final assessment that groundwater pollution risk potential are classifies $4,27 \%$ of the area as having very low, $15,12 \%$ of the area as having low, $20,17 \%$ as having moderate, $43,10 \%$ as having high, and $17,34 \%$ as having very high. The model was validated using E. Coli parameters as a represent of pollution risk where the results having exceeds $85 \%$ of total samples that a value exceeds from the standard of quality $>0 \mathrm{MPN} / 100 \mathrm{ml}$. However, this research is a preliminary to be continued in the further research.
\end{abstract}

\section{Introduction}

Yogyakarta city is an urban environment area in Indonesia, the population growth will increase from 422,732 people to 500,000 in 2030 with an average population growth of $1.04 \%$ [1]. In addition, the pressure of population factors from tourism activities where a number of tourist visits recorded in 2017 there were 3.89 million tourists with a proportion of foreign tourists $(11.2 \%)$ and domestic tourists $(88.8 \%)$ and an average length of stay is two days. Based on population and number of tourists, that can be implied that the number of people reached 1 million for the average mobility of people for a month. This number given the significant development of urban developments in the city of Yogyakarta, it is necessary to evaluate comprehensive the changes in the urban environment in Yogyakarta City and ensure the sustainability, especially the quality of groundwater.

In principle, the sustainability of an urban area can be seen from the adaptation process in maintaining a balance between ecosystem services and human well-being inside area. Sustainability includes three components of the environment, namely abiotic, biotic and cultural components. Environmental quality has a fundamental role in influencing the sustainability and sustainability of environmental quality degradation and vulnerability [2]. Therefore, in order to see the extent to which changes or dynamics of environmental quality can be evaluated through various methods. Dynamics of environmental quality can be evaluated especially the quality of groundwater by DRASTIC method, as like similar index models for generating data and the most established method that used by researcher, the method has been used for assessments such as study in Africa [3], USA [4], and China [5].

The method has advantages [6]: (1) using the method has a low cost use to be in cases, (2) using the method can be analysed for regional scale, because it is based on often easily for available datasets in cases, and (3) using a high number of input data layers is believed to limit the support of errors or uncertainties of the individual data layer in the final output. Despite advantages, the method has disadvantages that because using many parameters are required into the method. Some parameters are not significantly sensitive for groundwater pollution risk potential. However, the method can significantly be deployed to make regional or area scale assessment of groundwater vulnerability as screening how potential groundwater pollution risk is in research area.

\section{Materials and Methods}

\subsection{Research area description}

The research area is located in Yogyakarta City, show in Figure 1. The research area has complex characteristics with total area $\pm 32.53 \mathrm{~km}^{2}$. Population in Yogyakarta City is one of the most densely populated around 13,007 in habitants $/ \mathrm{km}^{2}$. The city consists of 14 districts and has a border with Sleman and Bantul regency. The development of the Yogyakarta city is generally influenced by the education, services and tourism.

\footnotetext{
* Corresponding author: syampadzi.nurroh@mail.ugm.ac.id
} 


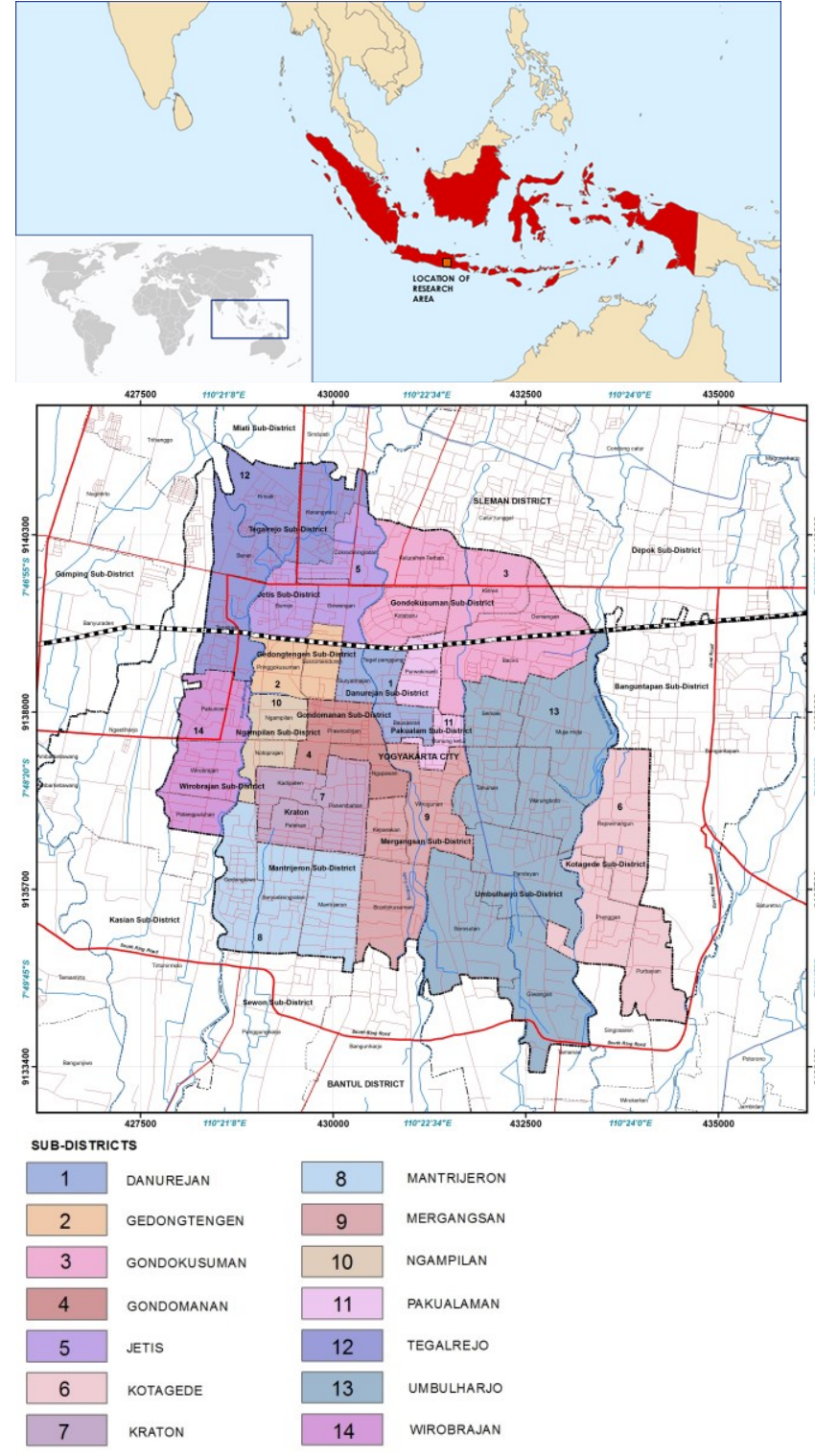

Fig. 1. Location of research area

\subsection{The DRASTIC model}

The DRASTIC model is used to evaluate groundwater vulnerability index to indicate pollution risk potential. This method describes the seven (7) parameters that are analysed with their abbreviations as defined according to previous research $[3,4,5]$ shown in Table 1 .

Table 1. Weight of DRASTIC parameters

\begin{tabular}{c|l|l|c}
\hline No & Symbol & \multicolumn{1}{|c}{ Parameter } & Weight \\
\hline 1 & $\left(\mathrm{D}_{\mathrm{w}}\right)$ & Depth to groundwater & 5 \\
\hline 2 & $\left(\mathrm{R}_{\mathrm{w}}\right)$ & Net Recharge & 4 \\
\hline 3 & $\left(\mathrm{Aw}_{\mathrm{w}}\right)$ & Aquifer media & 3 \\
\hline 4 & $\left(\mathrm{~S}_{\mathrm{w}}\right)$ & Soil media & 2 \\
\hline 5 & $\left(\mathrm{~T}_{\mathrm{w}}\right)$ & Topography & 1 \\
\hline 6 & $\left(\mathrm{I}_{\mathrm{w}}\right)$ & Impact of the vadose zone & 5 \\
\hline 7 & $\left(\mathrm{C}_{\mathrm{w}}\right)$ & Hydraulic Conductivity & 3 \\
\hline
\end{tabular}

The DRASTIC method as groundwater vulnerability index (rating $\times$ weight of each parameter) was calculated by the addition of the different data, using following the equation:

DI $=D_{w} \cdot D_{r, i}+R_{w} \cdot R_{r, i}+A_{w} \cdot A_{r, i}+S_{w} \cdot S_{r, i}+T_{w} \cdot T_{r, 1}+I_{w} \cdot I_{r, i}+C_{w} \cdot C_{r, i}$

Where DI, is vulnerability index (D, R, A, S, T, I, and C are the seven parameters) as defined in Table 1; and the subscripts $r, i$ and $w$ are the parameters rating for grid cell $i$ and weights.

Data came in various spatial resolutions shown in Table 2. The weights have relationship the relative importance of each parameter with respect to the other parameters. The weights parameter is constant for each parameter the designated rating varies from 1 to 10 and the rating ranges were determined depending on the properties at Yogyakarta City scale. the weights and rating ranges of the parameters shown in Table 3 dan Table 4. In general, the weights and ratings assigned in this research were similar to the typical ratings suggested in the original DRASTIC method.

\subsection{Data base compilation}

All data parameter (hydrogeology, geology, soil, groundwater recharge and topography) constructed by GIS database in Yogyakarta City scale. The metadata of the constructed GIS database, Data came in various spatial resolutions, therefore data layers to be suitable with the proposed resolution of the GIS model based 1: 35.000 scale for this research

\subsection{Development of DRASTIC parameters}

An overview of DRASTIC parameters develop where is each parameter as Depth to water (D), net Recharge (R), Aquifer media (A), Soil media (S), Topography (T), Impact of vadose zone (I), and Hydraulic conductivity (C) processed in the GIS is described below.

\subsubsection{Depth of groundwater (D)}

Term Depth to water table for initial D, This paramater refers to determinate of the vertical distance from the land surface to vadose zone in the aquifer. It can be described the distance that a potential contaminant migration to travel before end up to the aquifer. In general, the depth to groundwater is properly variable with respect to groundwater sensitivity, because the distance a contaminant flow through to the unsaturated zone before reaching the water table [7]. The distribution of the depth of groundwater parameter was inferred by subtracting the groundwater level from 80 (eighty) wells over the research area as presented by Public Works-Energy and Mineral Resource Office of D.I Yogyakarta. The weights and ratings for I are shown in Table 3. 
Table 2. The metadata of the constructed GIS database for DRASTIC parameters

\begin{tabular}{c|l|l|l|c|l}
\hline No & Source Data & Format & Input & Year & Output \\
\hline 1 & $\begin{array}{l}\text { Public Works-Energy and Mineral } \\
\text { Resource Office of D.I Yogyakarta }\end{array}$ & Xyzascii file & SV & 2015 & $\begin{array}{l}\text { Depth of } \\
\text { groundwater (D) }\end{array}$ \\
\hline 2 & BMKG D.I Yogyakarta & Shape file & Polygon area & 2018 & Recharge (R) \\
\hline 3 & $\begin{array}{l}\text { Public Works-Energy and Mineral } \\
\text { Resource Office of D.I Yogyakarta }\end{array}$ & $\begin{array}{l}\text { Raster File } \\
\text { Geodatabase }\end{array}$ & Polygon area & 2014 & Aquifer Media (A) \\
\hline 5 & $\begin{array}{l}\text { Agency for Agricultural Research } \\
\text { and Development }\end{array}$ & $\begin{array}{l}\text { Feature } \\
\text { Raster }\end{array}$ & Polygon area & 2014 & Soil Type (S) \\
\hline 6 & $\begin{array}{l}\text { Public Works-Energy and Mineral } \\
\text { Resource Office of D.I Yogyakarta }\end{array}$ & $\begin{array}{l}\text { Raster } \\
\text { File Geodatabase }\end{array}$ & Polygon area & 2014 & Topography (T) \\
\hline 7 & $\begin{array}{l}\text { Public Works-Energy and Mineral } \\
\text { Resource Office of D.I Yogyakarta }\end{array}$ & $\begin{array}{l}\text { Raster } \\
\text { File Geodatabase }\end{array}$ & Polygon area & 2014 & $\begin{array}{l}\text { Impact ff Vadose } \\
\text { Zone (I) }\end{array}$ \\
\hline
\end{tabular}

Table 3. Rate and weight of the seven DRASTIC parameters (DNTRC)

\begin{tabular}{l|c|c|c|c|l|l|l|l}
\hline \multicolumn{2}{l}{ Parameter (1) } & \multicolumn{2}{l|}{ Parameter (2) } & \multicolumn{2}{l}{ Parameter (3) } & \multicolumn{2}{l}{ Parameter (4) } \\
\hline $\begin{array}{l}\text { Depth of groundwater } \\
\text { (m) }\end{array}$
\end{tabular}

\subsubsection{Net Recharge (R)}

Term net recharge for initial R. This paramater refers to represents the amount of water per unit area of the land surface to vadose zone in the aquifer. The net recharge is influenced by the amount of surface runoff, the slope, and the permeability of the soil, the amount of water and the recharge of aquifer [8]. The net recharge parameter was derived by BMKG D.I Yogyakarta. The weights and ratings for I are shown in Table 3.

\subsubsection{Aquifer Media (A)}

Term Aquifer media for initial A, this paramater refers to determinate type of consolidated or unconsolidated material in the aquifer. In this research area, the lithological represents aquifer media were determined by Yogyakarta formation, which is a result of Merapi Volcano ejecta in Quaternary succession and composes of sand, gravel, silt and clay and Sentolo Formation, occurred in Tertiary succession and consists of marl, limestone and marly limestone [9]. The categories are unconsolidated sediments, according to the regional geological context, the research area are located in middle part of Yogyakarta basin. The vulnerability of the aquifer will increase if the grain size and the fractures or openings within the aquifer [10]. The Aquifer media were inferred by Public Works-Energy and Mineral Resource Office of D.I Yogyakarta. he weights and ratings for I are shown in Table 4.

\subsubsection{Soil Type (S)}

Term soil type for initial S, This paramater refers to represents that media the contaminant passes through when it percolates into vadose zone in the aquifer. According to impact soil type for contaminant [11], Soil type has a significant impact on the amount of recharge that can be infiltration into vadose zone in the aquifer and hence on the ability of a contaminant to move vertically. The soil type of Yogyakarta City was inferred from the data processed by Agency For Agricultural Research and 
Table 4. Rate and weight of the seven DRASTIC parameters (A and I)

\begin{tabular}{|c|c|c|c|c|c|}
\hline \multirow{4}{*}{ NO } & \multirow{4}{*}{ Lithology classes } & \multirow{4}{*}{ Hidrogeology } & \multirow{4}{*}{ Bedrock material } & Paramater (5) & Paramater (6) \\
\hline & & & & Tipe Aquifer & Tipe Vadose Zone \\
\hline & & & & weighting: 3 & weighting: 5 \\
\hline & & & & ratings & ratings \\
\hline \multirow[t]{3}{*}{1} & $\begin{array}{l}\text { Unconsolidated } \\
\text { sediments }\end{array}$ & Unconsolidated & & 8 & 8 \\
\hline & & c.g. unconsolidated & Alluvial deposits, dune sands & 8 & 8 \\
\hline & & f.g. unconsolidated & $\begin{array}{l}\text { Loess (Aeolian sediment), } \\
\text { organic sediment }\end{array}$ & 8 & 8 \\
\hline \multirow[t]{3}{*}{2} & $\begin{array}{l}\text { Siliciclastic } \\
\text { sediments }\end{array}$ & $\begin{array}{l}\text { Siliciclastic } \\
\text { sedimentary }\end{array}$ & Limestone, sandstone, & 6 & 6 \\
\hline & & $\begin{array}{l}\text { c.g. siliciclastic } \\
\text { sedimentary }\end{array}$ & Dolomite, siltstone, salt & 6 & 6 \\
\hline & & f.g. sedimentary & Conglomerate, shale & 6 & 6 \\
\hline 3 & $\begin{array}{l}\text { Mixed sedimentary } \\
\text { rocks }\end{array}$ & Carbonate & Karst limestone & 10 & 6 \\
\hline 4 & Acid volcanic rocks & Volcanic & Permeable basalt & 9 & 9 \\
\hline 5 & $\begin{array}{l}\text { Intermediate volcanic } \\
\text { rocks }\end{array}$ & & & 9 & 9 \\
\hline 6 & Basic volcanic rocks & & & 9 & 9 \\
\hline 7 & Acid plutonic rocks & Crystalline & Igneous/metamorphic rocks & 3 & 4 \\
\hline
\end{tabular}

Development where the uppermost part of study area is covered mostly by sand and sandy loam and greater grain sizes of geologic materials such as sand, coarse sand, and gravel, The weights and ratings for I are shown in Table 3.

\subsubsection{Topography $(T)$}

Term Topography for initial $\mathrm{T}$, this paramater refers to defines the runoff and infiltration capacity of the land surface into the soil through into vadose zone in the aquifer. The slope is an important parameter, which is more runoff will be generated and hence groundwater contamination risk will be low [3]. Therefore, it will be increasing the potential for introduce of contaminants. The slope were inferred by Public Works-Energy and Mineral Resource Office of D.I Yogyakarta and resampled and reclassified with the ratings into six classes in the research area. The weights and ratings for I are shown in Table 3.

\subsubsection{Impact of vadose zone (I)}

Term impact of vadose zone for initial I, this paramater refers to influences the residence time of pollutants in the unsaturated zone [7]. The role of the unsatured zone above the water table is integrated with respect to vadose zone. The vadose zone were inferred by Public WorksEnergy and Mineral Resource Office of D.I Yogyakarta It The weights and ratings for I are shown in Table 4.

\subsubsection{Hydraulic conductivity (C)}

Term the Hydraulic conductivity for initial $\mathrm{C}$, this paramater refers to measure of the ability aquifer for transmitting water when submitted to a hydraulic gradient that described how pollutants transfers by travel of velocity the pollutants, and hence the residence time and dilution which is a high conductivity will be related to high contamination pollution risks [10]. Aquifer media refers to the consolidated or unconsolidated material in the aquifer. then, hydraulic conductivity refers to the ability of the aquifer materials to transmit water, which is the rate can be controlled that groundwater will flow under a given hydraulic gradient [9]. Therefore, hydraulic conductivity is important parameter because it can be described for dilution which a contaminant will move flowing through into vadose zone in the aquifer. The hydraulic conductivity was inferred by Public WorksEnergy and Mineral Resource Office of D.I Yogyakarta. The weights and ratings for $\mathrm{C}$ are shown in Table 3 .

\subsection{Development of groundwater pollution risk}

The groundwater pollution risk related to the potential of a groundwater body for undergoing groundwater contamination [12]. The risk of pollution is determined both by the groundwater vulnerability index of the aquifer, which is relatively static, and the existence of potentially polluting activities at the soil surface. These latter activities are time dynamic and can be controlled [9]. Population density is often used as a proxy for pollution pressure at the soil surface and groundwater plays crucial role in urban environment as around $70 \%$ of population are using shallow wells. However, groundwater quality has been tremendously threatened by using on-site sanitation systems. In this research, the population density was inferred by Civil Registry Service Office of D.I Yogyakarta. The population density is grouped into five classes into very low, low, moderate, high and very high by generated the groundwater pollution risk index by combining the groundwater 
vulnerability index with the population density, using the following the equation:

$\mathbf{M D}_{\mathrm{I}}=\mathrm{D}_{\mathrm{w}} \cdot \mathrm{D}_{\mathrm{r}}+\mathrm{P}_{\mathrm{w}} \cdot \mathrm{P}_{\mathrm{r}}$

where $\mathrm{MD}_{\mathrm{I}}$ is the modified DRASTIC index for risk assessment, Di is the DRASTIC index and $\mathrm{P}_{\mathrm{w}} \times \mathrm{P}_{\mathrm{r}}$ is the multiplication of rating for grid cell $\mathrm{I}$ and weight for population density, using the following the equation:

$$
\operatorname{Pr}=\frac{\underline{D}_{i, j}-D_{i, \text { min. }}}{D_{i, \text { max }}-U_{i, \text { min }}}
$$

where Pr is the multiplication of rating for grid cell I for population density and $\mathrm{Pw}$ is the weighting for population density show in Table 5.

Table 5. Distribution and density of population parameters

\begin{tabular}{c|l|c|c|c}
\hline \multirow{2}{*}{ No } & \multirow{2}{*}{ District } & \multicolumn{2}{|c|}{ Parameter } & W:5 \\
\cline { 3 - 5 } & $\begin{array}{c}\text { Distribution } \\
\mathbf{( \% )}\end{array}$ & $\begin{array}{c}\text { Density } \\
(\mathbf{h a b i t a n t s} \\
\mathbf{/ K m}^{2} \mathbf{)}\end{array}$ & $\mathbf{P r}$ \\
\hline 1 & Danurejan & 4,52 & 17.389 & 8 \\
\hline 2 & Gedongtengen & 4,35 & 19.154 & 9 \\
\hline 3 & Gondokusuman & 11,23 & 11.895 & 7 \\
\hline 4 & Gondomanan & 3,24 & 12.229 & 8 \\
\hline 5 & Jetis & 5,67 & 14.108 & 9 \\
\hline 6 & Kotagede & 8,77 & 12.070 & 9 \\
\hline 7 & Kraton & 4,16 & 12.554 & 8 \\
\hline 8 & Mantrijeron & 7,90 & 12.799 & 8 \\
\hline 9 & Mergangsan & 7,25 & 13.275 & 8 \\
\hline 10 & Ngampilan & 4,03 & 20.770 & 9 \\
\hline 11 & Pakualaman & 2,21 & 14.827 & 9 \\
\hline 12 & Tegalrejo & 9,04 & 13.139 & 8 \\
\hline 13 & Umbulharjo & 21,47 & 11.179 & 7 \\
\hline 14 & Wirobrajan & 6,15 & 14.768 & 9 \\
\hline
\end{tabular}

The eight model (DRASTIC method and Population index) parameters of the groundwater pollution risk model were constructed, classified and encoded from several sources then overlaying each parameter in a GIS database.

\section{Results and discussions}

The result assessed the groundwater vulnerability index and groundwater pollution risk potential in Yogyakarta City scale, the result deployed the empirical of DRASTIC method into a GIS by is processed and overlay with ArcGIS $10.2^{\mathrm{TM}}$ and sensitivity parameter analysis is presented by Geoda ${ }^{\mathrm{TM}}$.

\subsection{Mapping of groundwater vulnerability index}

The groundwater vulnerability index was calculated (rating $\times$ weight of each parameter) by the addition of the different parameters, the resultant calculated each parameter. The groundwater vulnerability index map is show in Figure 2. Which is classified by 5 classes, with higher values describing greater vulnerable. The groundwater vulnerability index indicated that southern and a portion of the middle are dominated by having very high and high vulnerable. It is noticed that unsaturated zone in middle part having high vulnerable while most of southern having very high vulnerable, there is located in Mantrijeron, Mergangsan, Pakualam and Gondomanan district. This might be due to the reason that this area is mainly covered by coarse sand and mostly the settlement/tourism activity. The resultant classes index is shown in Table 6 where classes have been grouped overall into vulnerability interval index.

Table 6. The resultant of groundwater vulnerability

\begin{tabular}{c|l|c|c|c}
\hline No & Classes & $\begin{array}{c}\text { Intervals } \\
\text { Index }\end{array}$ & $\begin{array}{l}\text { Total } \\
\text { Area } \\
\text { (ha) }\end{array}$ & $\begin{array}{c}\text { Percentage } \\
(\%)\end{array}$ \\
\hline 1 & Very low & $<170$ & 18 & 0.55 \\
\hline 2 & Low & $170-174$ & 11 & 0.34 \\
\hline 3 & Moderate & $175-179$ & 811 & 24.93 \\
\hline 4 & High & $180-184$ & 646 & 19.86 \\
\hline 5 & Very high & $>184$ & 1767 & 54.32 \\
\hline
\end{tabular}

The result assessment that groundwater vulnerability index are classifies $0,55 \%$ of the area as having very low vulnerable, $0,34 \%$ as having low vulnerable, $24,93 \%$ as having moderate vulnerable, $19,86 \%$ as having high vulnerable, and $54,32 \%$ as having very high vulnerable.

\subsubsection{Statistical Summary of DRASTIC parameters}

A statistical summary of the seven (7) parameters is shown in Table. 7. This statistical summary presented the significance of each parameters in the assessment of the groundwater vulnerability index. On average rate values, the $\mathrm{T}$ parameter $($ mean $=9.38)$ has the highest number, the $\mathrm{D}($ mean $=9.32), \mathrm{R}($ mean $=9.00)$, and $\mathrm{A}($ mean $=8.83)$ parameter have a high number. The $\mathrm{I}($ mean $=8.00)$ and $\mathrm{S}$ (mean $=7.51)$ parameter have a moderate number. The $\mathrm{C}$ (mean $=3.67)$ parameter imply a low number. The coefficients of variation (CV) clarified that a high contribution to the variation of groundwater vulnerability index is purposed by $\mathrm{R}(92.30 \%), \mathrm{S}(76.49 \%)$ and $\mathrm{D}$ $(65.16 \%)$. Having moderate contribution is clarified with respect to variability of C (42.67\%) and A (39.62\%), and having low contribution is clarified with respect to variability of I (20.05\%) and T (18.53\%). In this research area, vadose zone and aquifer media are composed of the same material, A and I parameter have the same minimum values $(\mathrm{Min}=8)$ as value $\mathrm{S}$ and $\mathrm{A}$ the same minimun value $(\mathrm{Min}=2)$ expected to be the lowest.

Table 7. The resultant statistics summary

\begin{tabular}{c|l|c|c|c|c|c|c|c}
\hline No & $\begin{array}{l}\text { Source } \\
\text { Data }\end{array}$ & D & R & A & S & T & I & C \\
\hline 1 & Maximum & 10 & 9 & 9 & 9 & 10 & 8 & 4 \\
\hline 2 & Minimum & 8 & 9 & 8 & 2 & 9 & 8 & 2 \\
\hline 3 & Mean & 9.32 & 9.00 & 8.83 & 7.51 & 9.38 & 8.00 & 3.67 \\
\hline 4 & SD & 0.95 & 0.00 & 0.37 & 1.28 & 0.49 & 0.00 & 0.74 \\
\hline 5 & CV (\%) & 10.15 & 0.00 & 4.21 & 17.08 & 5.18 & 0.00 & 20.26 \\
\hline
\end{tabular}




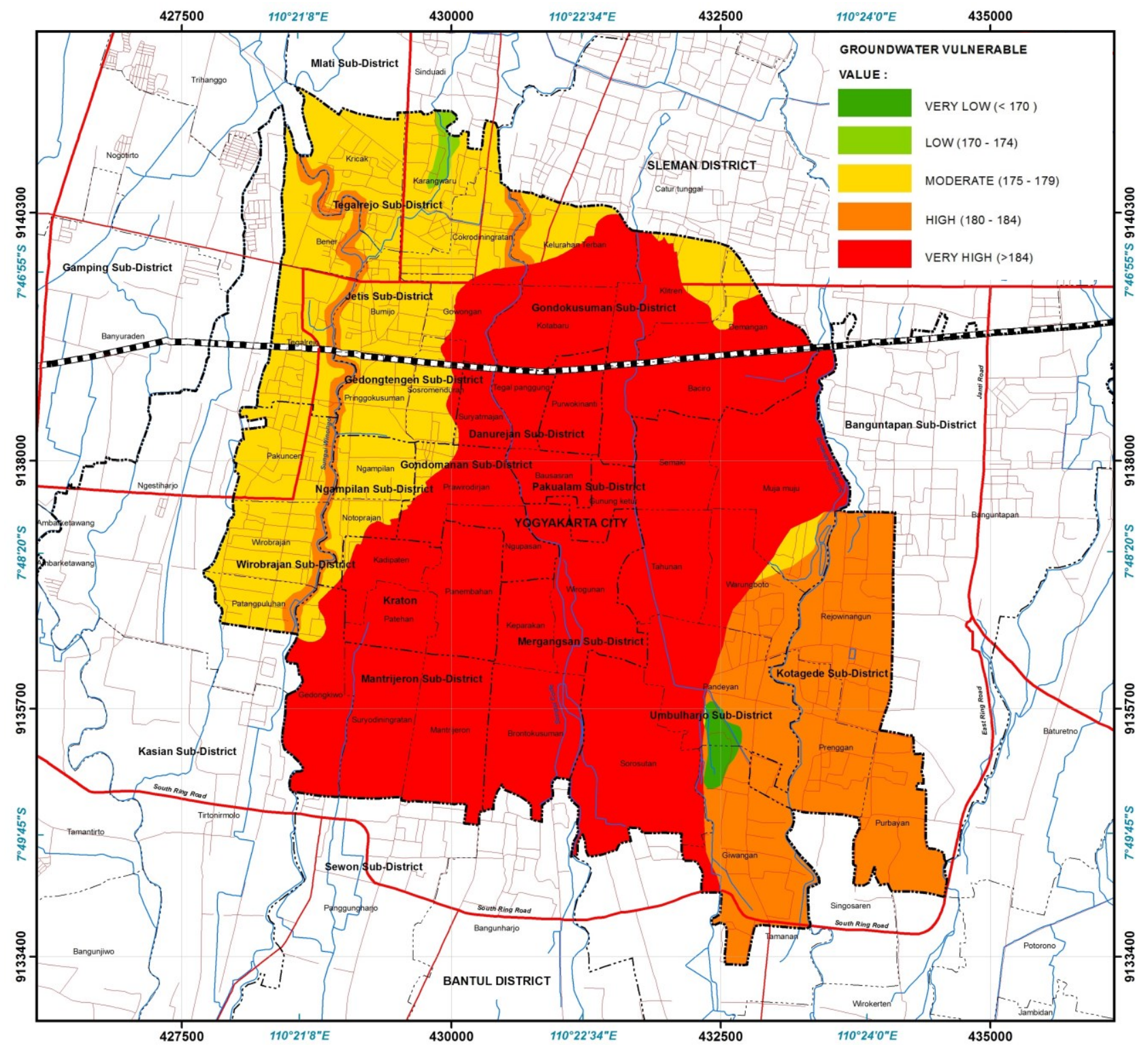

Fig. 2. Groundwater vulnerability index map

Table 8. The resultant summary statistics of sensitivity analysis

\begin{tabular}{c|l|c|c|c|c|c|c}
\hline \multirow{2}{*}{ No } & \multirow{2}{*}{ Parameters } & \multirow{2}{*}{$\begin{array}{l}\text { Theoretical } \\
\text { weight }\end{array}$} & \multirow{2}{*}{$\begin{array}{l}\text { Theoretical } \\
\text { weight (\%) }\end{array}$} & \multicolumn{4}{|c}{ Effective weight (\%) } \\
\cline { 5 - 8 } & & 5 & 21.74 & 16.73 & 17.39 & 16.95 & 24.71 \\
\hline 1 & Depth of groundwater (D) & 4 & 17.39 & 16.15 & 19.57 & 15.25 & 0.00 \\
\hline 2 & Recharge (R) & 3 & 13.04 & 15.86 & 17.39 & 15.25 & 9.70 \\
\hline 3 & Aquifer Media (A) & 2 & 8.70 & 13.48 & 15.25 & 4.35 & 33.50 \\
\hline 4 & Soil Type (S) & 1 & 4.35 & 16.84 & 19.57 & 16.95 & 12.68 \\
\hline 5 & Topography (T) & 5 & 21.74 & 14.36 & 17.39 & 13.56 & 0.00 \\
\hline 6 & Impact of Vadose Zone (I) & 3 & 13.04 & 6.58 & 4.35 & 6.78 & 19.41 \\
\hline 7 & Conductivity (C) & 23 & 100 & 100 & & & \\
\hline
\end{tabular}

\subsubsection{Parameter sensitivity analysis}

The single parameter sensitivity analysis allows the comparison between the effective and theoretical weights is shown in Table. 8. The effective weight of the DRASTIC parameter is a function of the theoretical weight and the interaction with the other parameters. The effective weight of the DRASTIC parameters obtained in this research exhibited some deviation from the theoretical weights. The Depth of groundwater (D) parameter tends to be the most effective parameter where D parameter has the highest effective weight values of the groundwater vulnerability index $(16,73 \%)$. The effective weight of the R, I, C parameter $(16.15 \%, 14,36 \%, 6,58 \%)$ 
is less than to its theoretical weight $(17.39 \%, 21,74 \%$, $13,04 \%)$. The effective weights: A, S and T $(15.86 \%$, $13.48 \%, 16,84)$ are higher than theoretical $(13.04 \%$, $8.70 \%, 4,35 \%)$. Based on The effective weight of the DRASTIC parameter The significance of parameters Depth of groundwater (D), aquifer media (A), topography (T), recharge (R), Impact Of Vadose Zone (I), soil type (S), and Conductivity (C), which explains their significantly contribution of the effective weight of the groundwater vulnerability index.

\subsection{Mapping of groundwater pollution risk}

The result of groundwater pollution risk potensial assessment is shown in Figure 3 and Table 9. The map classified into five classes to a very low, low, moderate, high and very high groundwater pollution risk potential. The result assessment that the final groundwater pollution risk potential for the research area classifies $4,27 \%$ of the area as having very low pollution risk potential, $15,12 \%$ of the area as having low pollution risk potential, 20,17\% as having moderate pollution risk potential, $43,10 \%$ as having high pollution risk potential, and $17,34 \%$ as having very high pollution risk potential.

Tabel 9. The resultant of groundwater pollution risk potential

\begin{tabular}{c|l|c|c|c}
\hline No & Classes & $\begin{array}{c}\text { Index } \\
\text { Intervals }\end{array}$ & $\begin{array}{c}\text { Total } \\
\text { Area } \\
\text { (ha) }\end{array}$ & $\begin{array}{c}\text { Percentage } \\
\text { (\%) }\end{array}$ \\
\hline 1 & Very low & $<170$ & 139 & 4.27 \\
\hline 2 & Low & $170-174$ & 492 & 15.12 \\
\hline 3 & Moderate & $175-179$ & 656 & 20.17 \\
\hline 4 & High & $180-184$ & 1402 & 43.10 \\
\hline 5 & Very high & $>184$ & 564 & 17.34 \\
\hline
\end{tabular}

We identified high to very high pollution risk classes, area having a low pollution risk does not having pollution risk, at least it is not significant potentially from groundwater contamination, but it is relatively less susceptible to contamination compared to other district. The density population in research area is expected due for explaining the risk potential. The groundwater pollution risk index indicated that southern and middle of area research are dominated by very high and high risk pollution potential (Danurejan, Gondomanan, Mantrijeron, Mergangsan, Pakualam and Gondomanan District). Therefore, assesement of groundwater pollution risk can be explained the the evidence of pollution (biological and/or chemical) and associated health problems were identified through water quality analysis [9] [12].

\subsection{Validation of groundwater pollution risk}

The above mentioned the DRASTIC method is an indirect method for evaluating groundwater pollution risk potential. Indeed, the use of methods that are not validated can result in erroneous conclusions. We measured quality of water, a total of 100 samples were taken from the water well. We selected parameters E. Coli concentrations in groundwater as a proxy since anthropogenic activities by urban development in Yogyakarta City show in Table.10 and Table.11.

Tabel 10. The existing of groundwater E.Coli concentration

\begin{tabular}{|c|c|c|c|}
\hline No & Coordinate & $\begin{array}{c}\text { Well } \\
\text { Depth (m) }\end{array}$ & $\begin{array}{c}\text { E.Coli } \\
(\mathrm{MPN} / 100 \mathrm{ml})\end{array}$ \\
\hline 1. & $\begin{array}{l}\mathrm{X}: 110^{\circ}, 23^{\prime} 33.2^{\prime \prime} \mathrm{Y}:-7 \\
\text { o } 47^{\prime} 20.8^{\prime},\end{array}$ & 6.50 & 94 \\
\hline 2. & $\begin{array}{l}\mathrm{X}: 110^{\circ}, 23^{\prime} 51.0^{\prime \prime} \mathrm{Y}:-7 \\
{ }^{\circ}, 48^{\prime} 01.7^{\prime},\end{array}$ & 8.00 & 15 \\
\hline 3. & $\begin{array}{l}\mathrm{X}: 110^{\circ}, 23^{\prime} 51.0^{\prime \prime} \mathrm{Y}:-7 \\
{ }^{\circ}, 48^{\prime} 01.7^{\prime \prime}\end{array}$ & 8.00 & TNCT* \\
\hline 4. & $\begin{array}{l}\mathrm{X}: 110^{\circ}, 23^{\prime} 54.5^{\prime \prime} \mathrm{Y}:-7 \\
{ }^{\circ}, 48^{\prime} 20.8^{\prime},\end{array}$ & 7.10 & 21 \\
\hline 5. & $\begin{array}{l}\mathrm{X}: 110^{\circ}, 24^{\prime} 13.2^{\prime \prime} \mathrm{Y}:-7 \\
\text { o,48'17.9," }\end{array}$ & 4.70 & TNCT \\
\hline 6. & $\begin{array}{l}\mathrm{X}: 110^{\circ}, 24^{\prime} 03.8^{\prime \prime} \mathrm{Y}:-7 \\
{ }^{\circ}, 47^{\prime} 59.7^{\prime}\end{array}$ & 4.10 & 4 \\
\hline 7. & $\begin{array}{l}\mathrm{X}: 110^{\circ}, 24^{\prime} 16.6^{\prime} \mathrm{Y}:-7 \\
{ }^{\circ}, 48^{\prime} 42.1^{\prime \prime}\end{array}$ & 2.60 & 33 \\
\hline 8. & $\begin{array}{l}\mathrm{X}: 110^{\circ}, 24^{\prime} 12.9^{\prime \prime} \mathrm{Y}:-7 \\
\text { o,49’05.8," }\end{array}$ & 3.10 & 22 \\
\hline 9. & $\begin{array}{l}\mathrm{X}: 110^{\circ}, 23^{\prime} 53.2^{\prime \prime} \mathrm{Y}:-7 \\
{ }^{\circ}, 48^{\prime} 38.6^{\prime \prime}\end{array}$ & 6.40 & 0 \\
\hline 10. & $\begin{array}{l}\mathrm{X}: 110^{\circ}, 23^{\prime} 47.5^{\prime \prime} \mathrm{Y}:-7 \\
{ }^{\circ}, 49^{\prime} 04.2^{\prime \prime}\end{array}$ & 8.60 & 23 \\
\hline 11. & $\begin{array}{l}\mathrm{X}: 110^{\circ}, 23^{\prime} 54.1^{\prime \prime} \mathrm{Y}:-7 \\
{ }^{\circ}, 49^{\prime} 18.2^{\prime},\end{array}$ & 3.80 & 4 \\
\hline 12. & $\begin{array}{l}\mathrm{X}: 110^{\circ}, 24^{\prime} 09.7^{\prime \prime} \mathrm{Y}:-7 \\
\mathrm{o}^{\circ}, 49^{\prime} 21.0^{\prime \prime}\end{array}$ & 2.50 & TNCT \\
\hline 13. & $\begin{array}{l}\mathrm{X}: 110^{\circ}, 24^{\prime} 14.3^{\prime \prime} \mathrm{Y}:-7 \\
\text { o }_{4} 49^{\prime} 28.3^{\prime},\end{array}$ & 3.20 & TNCT \\
\hline 14. & $\begin{array}{l}\mathrm{X}: 110^{\circ}, 23^{\prime} 47.5^{\prime \prime} \mathrm{Y}:-7 \\
\mathrm{o}^{\circ}, 49^{\prime} 3.1^{\prime},\end{array}$ & 6.90 & 9 \\
\hline 15. & $\begin{array}{l}\mathrm{X}: 110^{\circ}, 23^{\prime} 53.3^{\prime \prime} \mathrm{Y}:-7 \\
{ }^{\circ}, 50^{\prime} 02.8^{\prime},\end{array}$ & 3.50 & TNCT \\
\hline 16. & $\begin{array}{l}\mathrm{X}: 110^{\circ}, 24^{\prime} 12.2^{\prime \prime} \mathrm{Y}:-7 \\
\text { o,49’58.7”, }\end{array}$ & 5.35 & TNCT \\
\hline 17. & $\begin{array}{l}\mathrm{X}: 110^{\circ}, 24^{\prime} 02.7^{\prime \prime} \mathrm{Y}:-7 \\
{ }^{\circ}, 50^{\prime} 26.3^{\prime \prime}\end{array}$ & 4.60 & TNCT \\
\hline 18. & $\begin{array}{l}\mathrm{X}: 110^{\circ}, 23^{\prime} 26.3^{\prime \prime} \mathrm{Y}:-7 \\
{ }^{\circ}, 48^{\prime} 36.9^{\prime \prime}\end{array}$ & 3.10 & 94 \\
\hline 19. & $\begin{array}{l}\mathrm{X}: 110^{\circ}, 23^{\prime} 22.8^{\prime \prime} \mathrm{Y}:-7 \\
{ }^{\circ}, 48^{\prime} 20.8^{\prime \prime}\end{array}$ & 4.20 & 46 \\
\hline 20. & $\begin{array}{l}\mathrm{X}: 110^{\circ}, 22^{\prime} 59.6^{\prime \prime} \mathrm{Y}:-7 \\
{ }^{\circ}, 48^{\prime} 46.9^{\prime \prime}\end{array}$ & 2.50 & 0 \\
\hline 21. & $\begin{array}{l}\mathrm{X}: 110^{\circ}, 23^{\prime} 10.9^{\prime \prime} \mathrm{Y}:-7 \\
{ }^{\circ}, 48^{\prime} 52.9^{\prime},\end{array}$ & 2.80 & 0 \\
\hline 22. & $\begin{array}{l}\mathrm{X}: 110^{\circ}, 23^{\prime} 17.9^{\prime \prime} \mathrm{Y}:-7 \\
\text { o,49'14.4”, }\end{array}$ & 4.60 & TNCT \\
\hline 23. & $\begin{array}{l}\mathrm{X}: 110^{\circ}, 23^{\prime} 10.8^{\prime \prime} \mathrm{Y}:-7 \\
\mathrm{o}^{\prime}, 49^{\prime} 45.5^{\prime},\end{array}$ & 1.30 & 0 \\
\hline 24. & $\begin{array}{l}\mathrm{X}: 110^{\circ}, 23^{\prime} 33.2^{\prime \prime} \mathrm{Y}:-7 \\
{ }^{\circ}, 47^{\prime} 20.8^{\prime \prime}\end{array}$ & 6.20 & 2 \\
\hline 25. & $\begin{array}{l}\mathrm{X}: 110^{\circ}, 23^{\prime} 33.2^{\prime \prime} \mathrm{Y}:-7 \\
{ }^{\circ}, 50^{\prime} 26.0^{\prime \prime}\end{array}$ & 1.30 & TNCT \\
\hline 26. & $\begin{array}{l}\mathrm{X}: 110^{\circ}, 23^{\prime} 21.1^{\prime \prime} \mathrm{Y}:-7 \\
{ }^{\circ}, 50^{\prime} 30.1^{\prime \prime}\end{array}$ & 2.00 & 5 \\
\hline 27. & $\begin{array}{l}\mathrm{X}: 110^{\circ}, 23^{\prime} 46.9^{\prime \prime} \mathrm{Y}:-7 \\
{ }^{\circ}, 50^{\prime} 38.1^{\prime \prime}\end{array}$ & 4.40 & 5 \\
\hline 28. & $\begin{array}{l}\mathrm{X}: 110^{\circ}, 22^{\prime} 39.9^{\prime \prime} \mathrm{Y}:-7 \\
{ }^{\circ}, 50^{\prime} 16.2^{\prime \prime}\end{array}$ & 3.10 & 9 \\
\hline 29. & $\begin{array}{l}\mathrm{X}: 110^{\circ}, 22^{\prime} 37.6 . " Y:-7 \\
{ }^{\circ}, 50 ’ 35.1^{\prime},\end{array}$ & 2.70 & 4 \\
\hline 30. & $\begin{array}{l}\mathrm{X}: 110^{\circ}, 22^{\prime} 16.4^{\prime \prime} \mathrm{Y}:-7 \\
{ }^{\circ}, 50^{\prime} 23.2^{\prime \prime}\end{array}$ & 1.60 & 0 \\
\hline 31. & $\begin{array}{l}\mathrm{X}: 110^{\circ}, 21^{\prime} 54.9^{\prime \prime} \mathrm{Y}:-7 \\
{ }^{\circ}, 50^{\prime} 38.5^{\prime},\end{array}$ & 1.40 & 5 \\
\hline 32. & $\begin{array}{l}\mathrm{X}: 110^{\circ}, 22^{\prime} 39.3^{\prime \prime} \mathrm{Y}:-7 \\
{ }^{\circ}, 49^{\prime} 58.7^{\prime},\end{array}$ & 7.50 & TNCT \\
\hline
\end{tabular}




\begin{tabular}{|c|c|c|c|}
\hline No & Coordinate & $\begin{array}{c}\text { Well } \\
\text { Depth (m) }\end{array}$ & $\begin{array}{c}\text { E.Coli } \\
(\mathrm{MPN} / 100 \mathrm{ml}) \\
\end{array}$ \\
\hline 33. & $\begin{array}{l}\text { X: } 110^{\circ}, 22^{\prime} 13.3^{\prime \prime} Y:-7 \\
{ }^{\circ}, 49^{\prime} 51.1^{\prime \prime}\end{array}$ & 5.30 & 0 \\
\hline 34. & $\begin{array}{l}\mathrm{X}: 110^{\circ}, 22^{\prime} 46.7^{\prime \prime} \mathrm{Y}:-7 \\
\text { o,49'26.9", }\end{array}$ & 4.80 & 4 \\
\hline 35. & $\begin{array}{l}\mathrm{X}: 110^{\circ}, 22^{\prime} 34.8^{\prime \prime} \mathrm{Y}:-7 \\
\text { o,49'11.3", }\end{array}$ & 3.00 & 0 \\
\hline 36. & $\begin{array}{l}\mathrm{X}: 110^{\circ}, 23{ }^{\prime} 24.3^{\prime \prime} \mathrm{Y}:-7 \\
{ }^{\circ}, 47^{\prime} 02.1^{\prime \prime}\end{array}$ & 8.40 & 23 \\
\hline 37. & $\begin{array}{l}\text { X: } 110^{\circ}, 23 \text { '25.4"Y: }-7 \\
\text { o,46'49.8”, }\end{array}$ & 8.90 & 0 \\
\hline 38. & $\begin{array}{l}\mathrm{X}: 110^{\circ}, 23^{\prime} 23.8^{\prime \prime} \mathrm{Y}:-7 \\
{ }^{\circ}, 466^{\prime} 26.9^{\prime \prime}\end{array}$ & 10.0 & 4 \\
\hline 39. & $\begin{array}{l}\mathrm{X}: 110^{\circ}, 23^{\prime} 26.5^{\prime \prime} \mathrm{Y}:-7 \\
{ }^{\circ}, 46^{\prime} 14.1^{\prime \prime}\end{array}$ & 8.20 & 4 \\
\hline 40. & $\begin{array}{l}\mathrm{X}: 110^{\circ}, 22^{\prime} 46.0^{\prime \prime} \mathrm{Y}:-7 \\
{ }^{\circ}, 46^{\prime} 37.2^{\prime \prime}\end{array}$ & 8.60 & 9 \\
\hline 41. & $\begin{array}{l}\text { X: } 110^{\circ}, 22^{\prime} 48.3^{\prime \prime} Y:-7 \\
\text { o,46'45.3", }\end{array}$ & 7.50 & 0 \\
\hline 42. & $\begin{array}{l}\mathrm{X}: 110^{\circ}, 22^{\prime} 48.3^{\prime \prime} \mathrm{Y}:-7 \\
\text { o,47'03.9", }\end{array}$ & 7.50 & 0 \\
\hline 43. & $\begin{array}{l}\mathrm{X}: 110^{\circ}, 22^{\prime} 48.5^{\prime \prime} \mathrm{Y}:-7 \\
{ }^{\circ}, 47^{\prime} 18.2^{\prime \prime}\end{array}$ & 7.40 & 4 \\
\hline 44. & $\begin{array}{l}\mathrm{X}: 110^{\circ}, 22^{\prime} 46.2^{\prime \prime} \mathrm{Y}:-7 \\
{ }^{\circ}, 49^{\prime} 04.9^{\prime \prime}\end{array}$ & 1.80 & TNCT \\
\hline 45. & $\begin{array}{l}\mathrm{X}: 110^{\circ}, 21^{\prime} 36.0^{\prime \prime} \mathrm{Y}:-7 \\
{ }^{\circ}, 49^{\prime} 54.6^{\prime \prime}\end{array}$ & 2.30 & TNCT \\
\hline 46. & $\begin{array}{l}\mathrm{X}: 110^{\circ}, 21^{\prime} 25.8^{\prime \prime} \mathrm{Y}:-7 \\
{ }^{\circ}, 500^{\prime} 26.2^{\prime \prime}\end{array}$ & 1.00 & TNCT \\
\hline 47. & $\begin{array}{l}\mathrm{X}: 110^{\circ}, 21^{\prime} 15.8^{\prime \prime} \mathrm{Y}:-7 \\
{ }^{\circ}, 50^{\prime} 37.7^{\prime \prime}\end{array}$ & 0.50 & 4 \\
\hline 48. & $\begin{array}{l}\text { X: } 110^{\circ}, 21^{\prime} 08.7^{\prime \prime} Y:-7 \\
\text { o } 49^{\prime} 45.0^{\prime \prime}\end{array}$ & 2.50 & TNCT \\
\hline 49. & $\begin{array}{l}\mathrm{X}: 110^{\circ}, 21^{\prime} 12.9^{\prime \prime} \mathrm{Y}:-7 \\
\text { ',49'32.9', }\end{array}$ & 2.20 & 4 \\
\hline 50. & $\begin{array}{l}\mathrm{X}: 110^{\circ}, 21^{\prime} 11.3^{\prime \prime} \mathrm{Y}:-7 \\
\text { o,49'18.9," }\end{array}$ & 5.10 & 4 \\
\hline 51. & $\begin{array}{l}\text { X: } 110^{\circ}, 22^{\prime} 10 . " Y:-7 \\
\text { o,46'27.6", } \\
\text {, }\end{array}$ & 3.40 & 3 \\
\hline 52. & $\begin{array}{l}\mathrm{X}: 110^{\circ}, 22^{\prime} 13.1^{\prime \prime} \mathrm{Y}:-7 \\
{ }^{\circ}, 46^{\prime} 13.1^{\prime \prime}\end{array}$ & 11.7 & 9 \\
\hline 53. & $\begin{array}{l}\text { X: } 110^{\circ}, 22^{\prime} 12.8^{\prime \prime} Y:-7 \\
\text { o } 466^{\prime} 45.8^{\prime \prime}\end{array}$ & 3.40 & 98 \\
\hline 54. & $\begin{array}{l}\text { X: } 110^{\circ}, 22^{\prime} 16.7^{\prime \prime} Y:-7 \\
\text { o,46'59.4", }\end{array}$ & 5.80 & TNCT \\
\hline 55. & $\begin{array}{l}\mathrm{X}: 110^{\circ}, 22^{\prime} 13.7^{\prime \prime} \mathrm{Y}:-7 \\
{ }^{\circ}, 47^{\prime} 22.2^{\prime \prime}\end{array}$ & 7.55 & 19 \\
\hline 56. & $\begin{array}{l}\mathrm{X}: 110^{\circ}, 22^{\prime} 12.0^{\prime \prime} \mathrm{Y}:-7 \\
{ }^{\circ}, 47^{\prime} 48.0^{\prime \prime}\end{array}$ & 3.70 & 24 \\
\hline 57. & $\begin{array}{l}\text { X: } 110^{\circ}, 22^{\prime} 19.3^{\prime \prime} Y:-7 \\
\text { o, } 48^{\prime} 17.8^{\prime \prime}\end{array}$ & 4.70 & 3 \\
\hline 58. & $\begin{array}{l}\mathrm{X}: 110^{\circ}, 22^{\prime} 19.3^{\prime \prime} \mathrm{Y}:-7 \\
{ }^{\circ}, 48^{\prime} 17.8^{\prime \prime}\end{array}$ & 1.70 & 2 \\
\hline 59. & $\begin{array}{l}\mathrm{X}: 110^{\circ}, 22^{\prime} 19.5^{\prime \prime} \mathrm{Y}:-7 \\
\text { o,49'04.4", }\end{array}$ & 4.80 & 0 \\
\hline 60. & $\begin{array}{l}\mathrm{X}: 110^{\circ}, 22^{\prime} 07.3^{\prime \prime} \mathrm{Y}:-7 \\
\text { o,49'19.6", }\end{array}$ & 4.10 & 44 \\
\hline 61. & $\begin{array}{l}\mathrm{X}: 110^{\circ}, 21^{\prime} 57.1^{\prime \prime} \mathrm{Y}:-7 \\
{ }^{\circ}, 49^{\prime} 32.3^{\prime \prime}\end{array}$ & 3.60 & 70 \\
\hline 62. & $\begin{array}{l}\mathrm{X}: 110^{\circ}, 21^{\prime} 40.9^{\prime \prime} \mathrm{Y}:-7 \\
{ }^{\circ}, 49^{\prime} 29.2^{\prime \prime}\end{array}$ & 3.30 & 51 \\
\hline 63. & $\begin{array}{l}\mathrm{X}: 110^{\circ}, 21^{\prime} 40.5^{\prime \prime} \mathrm{Y}:-7 \\
\text { o,49'17.9", }\end{array}$ & 2.90 & 10 \\
\hline 64. & $\begin{array}{l}\mathrm{X}: 110^{\circ}, 21^{\prime} 38.5^{\prime \prime} \mathrm{Y}:-7 \\
\text { o, } 48^{\prime} 45.5^{\prime \prime}\end{array}$ & 3.00 & 12 \\
\hline 65. & $\begin{array}{l}\text { X: } 110^{\circ}, 21^{\prime} 05.4^{\prime \prime} Y:-7 \\
{ }^{\circ}, 45^{\prime} 56.5^{\prime},\end{array}$ & 7.80 & 21 \\
\hline 66. & $\begin{array}{l}\text { X: } 110^{\circ}, 21^{\prime} 25.7^{\prime \prime} Y:-7 \\
\text { o, } 46^{\prime} 10.5^{\prime \prime}\end{array}$ & 10.30 & 18 \\
\hline 67. & $\begin{array}{l}\text { X: } 110^{\circ}, 21^{\prime} 39.6^{\prime \prime} Y:-7 \\
\text { `,46'14.8," }\end{array}$ & 7.60 & 30 \\
\hline 68. & $\begin{array}{l}\mathrm{X}: 110^{\circ}, 21^{\prime} 34.7^{\prime \prime} \mathrm{Y}:-7 \\
\text { o,45'53.4," }\end{array}$ & 8.50 & 49 \\
\hline
\end{tabular}

\begin{tabular}{|c|c|c|c|}
\hline No & Coordinate & $\begin{array}{c}\text { Well } \\
\text { Depth (m) }\end{array}$ & $\begin{array}{c}\text { E.Coli } \\
\text { (MPN/100 ml) } \\
\end{array}$ \\
\hline 69. & $\begin{array}{l}\mathrm{X}: 110^{\circ}, 21^{\prime} 34.6^{\prime \prime} \mathrm{Y}:-7 \\
\text { ॰,46’27.9," }\end{array}$ & 7.60 & 37 \\
\hline 70. & $\begin{array}{l}\mathrm{X}: 110^{\circ}, 21{ }^{\prime} 11.5^{\prime \prime} \mathrm{Y}:-7 \\
\text { o,46'25.0", }\end{array}$ & 3.40 & 31 \\
\hline 71. & $\begin{array}{l}\text { X: } 110^{\circ}, 21{ }^{\prime} 08.8^{\prime \prime} Y:-7 \\
\text { o } 46^{\prime} 47.5^{\prime \prime}\end{array}$ & 5.50 & TNCT \\
\hline 72. & $\begin{array}{l}\text { X: } 110^{\circ}, 21{ }^{\prime} 10.3^{\prime \prime} Y:-7 \\
\text { o,47'27.6", } \\
\text {, }\end{array}$ & 10.10 & 5 \\
\hline 73. & $\begin{array}{l}\mathrm{X}: 110^{\circ}, 21{ }^{\prime} 22.0^{\prime \prime} \mathrm{Y}:-7 \\
{ }^{\circ}, 47^{\prime} 05.6^{\prime \prime}\end{array}$ & 8.70 & TNCT \\
\hline 74. & $\begin{array}{l}\text { X: } 110^{\circ}, 211^{\prime} 29.0^{\prime \prime} \mathrm{Y}:-7 \\
\text { o } 46^{\prime} 47.2^{\prime \prime}\end{array}$ & 8.60 & 160 \\
\hline 75. & $\begin{array}{l}\text { X: } 110^{\circ}, 23 \text { '44.3”Y: }-7 \\
\text { o, } 47^{\prime} 10.9^{\prime \prime}\end{array}$ & 4.30 & 18 \\
\hline 76. & $\begin{array}{l}\text { X: } 110^{\circ}, 211^{\prime} 25.8^{\prime \prime} Y:-7 \\
{ }^{\circ}, 50^{\prime} 26.2^{\prime}\end{array}$ & 7.40 & 2 \\
\hline 77. & $\begin{array}{l}\text { X: } 110^{\circ}, 21{ }^{\prime} 15.8^{\prime \prime} Y:-7 \\
{ }^{\circ}, 500^{\prime} 37.7^{\prime \prime}\end{array}$ & 3.60 & 34 \\
\hline 78. & $\begin{array}{l}\mathrm{X}: 110^{\circ}, 22^{\prime} 58.4^{\prime \prime} \mathrm{Y}:-7 \\
\text { o,48'13.5', }\end{array}$ & 8.75 & TNCT \\
\hline 79. & $\begin{array}{l}\mathrm{X}: 110^{\circ}, 22^{\prime} 45.5^{\prime \prime} \mathrm{Y}:-7 \\
{ }^{\circ}, 48^{\prime} 03.2^{\prime \prime}\end{array}$ & 4.00 & 17 \\
\hline 80. & $\begin{array}{l}\mathrm{X}: 110^{\circ}, 22^{\prime} 49.2^{\prime \prime} \mathrm{Y}:-7 \\
\text { o,47'53.4", }\end{array}$ & 8.75 & 18 \\
\hline 81. & $\begin{array}{l}\text { X: } 110^{\circ}, 20^{\prime} 32.0^{\prime \prime} \mathrm{Y}:-7 \\
\text { o, } 49^{\prime} 45.3^{\prime \prime}\end{array}$ & 2.60 & 83 \\
\hline 82. & $\begin{array}{l}\text { X: } 110^{\circ}, 20{ }^{\prime} 39.0^{\prime \prime} \mathrm{Y}:-7 \\
{ }^{\circ}, 49^{\prime} 25.5^{\prime \prime}\end{array}$ & 7.10 & 64 \\
\hline 83. & $\begin{array}{l}\text { X: } 110^{\circ}, 20^{\prime} 37.1^{\prime \prime} Y:-7 \\
\text { o,49'13.4”, }\end{array}$ & 11.6 & 83 \\
\hline 84. & $\begin{array}{l}\text { X: } 110^{\circ}, 21{ }^{\prime} 10.3^{\prime \prime} Y:-7 \\
\text { o, } 48^{\prime} 57.3^{\prime \prime}\end{array}$ & 6.30 & 0 \\
\hline 85. & $\begin{array}{l}\mathrm{X}: 110^{\circ}, 22^{\prime} 07.3^{\prime \prime} \mathrm{Y}:-7 \\
\text { o, } 49^{\prime} 19.6^{\prime \prime}\end{array}$ & 9.20 & 2 \\
\hline 86. & $\begin{array}{l}\text { X: } 110^{\circ}, 20^{\prime} 50.7^{\prime \prime} Y:-7 \\
\text { o } 48^{\prime} 33.9^{\prime \prime}\end{array}$ & 6.10 & 4 \\
\hline 87. & $\begin{array}{l}\text { X: } 110^{\circ}, 20{ }^{\prime} 49.5^{\prime \prime} Y:-7 \\
\text { o }, 48^{\prime} 17.5^{\prime \prime}\end{array}$ & 11.60 & 60 \\
\hline 88. & $\begin{array}{l}\text { X: } 110^{\circ}, 21 \text { '16.6” Y: }-7 \\
\text { o,48'12.9", }\end{array}$ & 6.10 & 19 \\
\hline 89. & $\begin{array}{l}\text { X: } 110^{\circ}, 211^{\prime} 27.6^{\prime \prime} Y:-7 \\
\text { o, } 47^{\prime} 59.8^{\prime \prime}\end{array}$ & 6.60 & 0 \\
\hline 90. & $\begin{array}{l}\text { X: } 110^{\circ}, 21{ }^{\prime} 38.6^{\prime \prime} Y:-7 \\
{ }^{\circ}, 48^{\prime} 12.7^{\prime \prime}\end{array}$ & 6.60 & 0 \\
\hline 91. & $\begin{array}{l}\text { X: } 110^{\circ}, 22{ }^{\prime} 26.7^{\prime \prime} Y:-7 \\
{ }^{\circ}, 48^{\prime} 51.7^{\prime \prime}\end{array}$ & 1.50 & 12 \\
\hline 92. & $\begin{array}{l}\text { X: } 110^{\circ}, 21^{\prime} 40.1^{\prime \prime} Y:-7 \\
\text { o, } 49^{\prime} 03.1^{\prime \prime}\end{array}$ & 7.90 & 70 \\
\hline 93. & $\begin{array}{l}\mathrm{X}: 110^{\circ}, 22^{\prime} 01.3^{\prime \prime} \mathrm{Y}:-7 \\
{ }^{\circ}, 48^{\prime} 43.3^{\prime \prime}\end{array}$ & 6.90 & 0 \\
\hline 94. & $\begin{array}{l}\text { X: } 110^{\circ}, 20^{\prime} 59.4^{\prime \prime} Y:-7 \\
\text { o,47'59.1", }\end{array}$ & 8.60 & 18 \\
\hline 95. & $\begin{array}{l}\text { X: } 110^{\circ}, 21{ }^{\prime} 34.8^{\prime \prime} Y:-7 \\
\text { ',47'44.7', }\end{array}$ & 5.00 & 15 \\
\hline 96. & $\begin{array}{l}\text { X: } 110^{\circ}, 22^{\prime} 00.0^{\prime \prime} \mathrm{Y}:-7 \\
{ }^{\circ}, 48^{\prime} 14.6^{\prime \prime}\end{array}$ & 7.40 & 4 \\
\hline 97. & $\begin{array}{l}\mathrm{X}: 110^{\circ}, 21^{\prime} 03.2^{\prime \prime} \mathrm{Y}:-7 \\
\text { o, } 47^{\prime} 39.3^{\prime \prime}\end{array}$ & 10.40 & 121 \\
\hline 98. & $\begin{array}{l}\text { X: } 110^{\circ}, 211^{\prime} 33.7^{\prime \prime} Y:-7 \\
\text { o } 47^{\prime} 22.8^{\prime \prime}\end{array}$ & 8.70 & TNCT \\
\hline 99. & $\begin{array}{l}\text { X: } 110^{\circ}, 22^{\prime} 50.9^{\prime \prime} Y:-7 \\
\text { o,46'11.5" }\end{array}$ & 8.70 & TNCT \\
\hline 100 & $\begin{array}{l}\mathrm{X}: 110^{\circ}, 22^{\prime} 50.9^{\prime \prime} \mathrm{Y}:-7 \\
\text { o,46’11.5”, }\end{array}$ & 8.80 & 2 \\
\hline
\end{tabular}

*Too Numerous To Count 
Tabel 11. The resume of groundwater E.Coli concentration

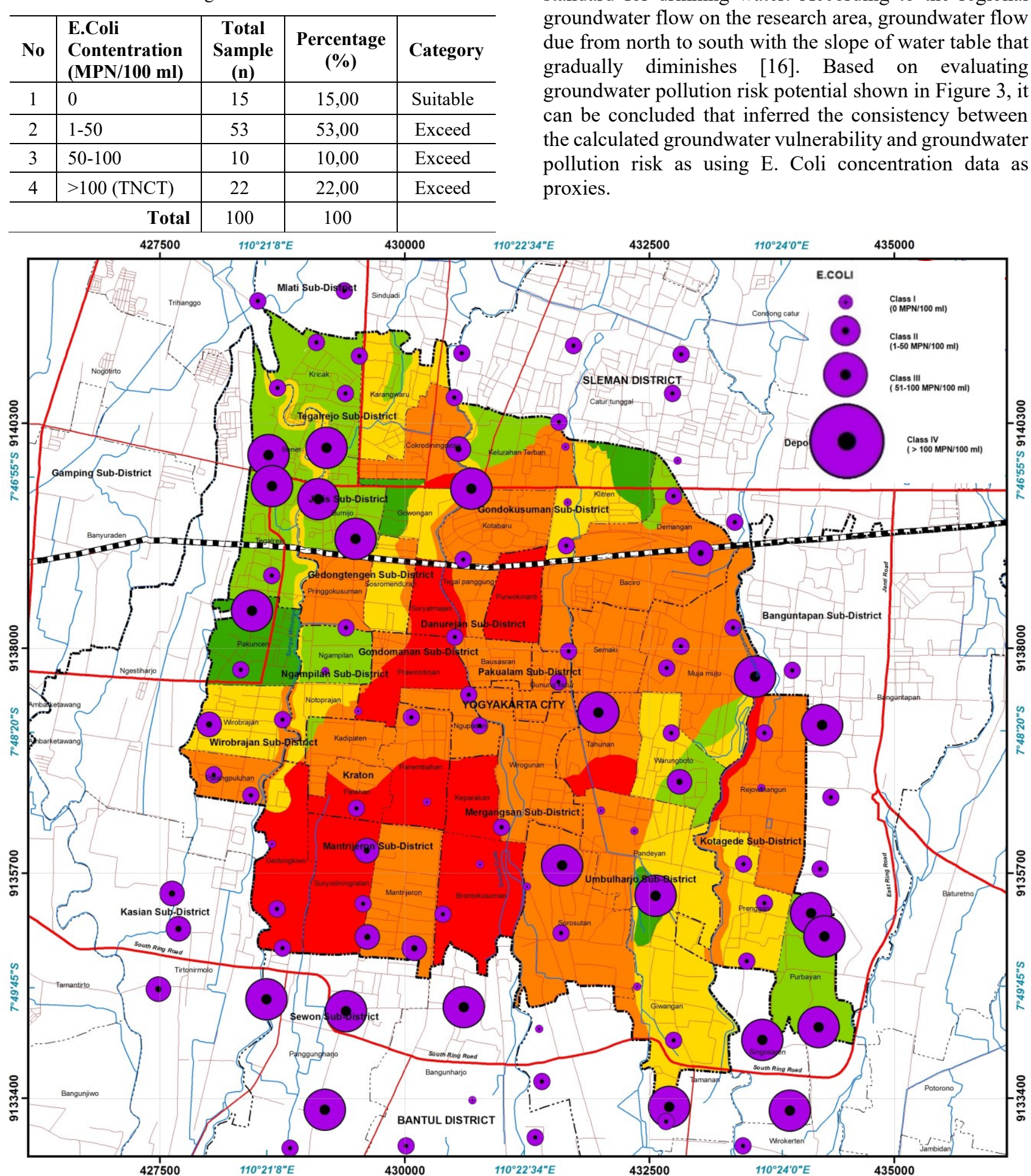

Fig. 3. Groundwater pollution risk potential map

E. Coli as an indicator of groundwater pollution whereas E. Coli was divided into two categories based on guidelines for drinking water are $0 \mathrm{MPN} / \mathrm{ml}$ and $>0$ $\mathrm{MPN} / 100 \mathrm{ml}$ [13] [14]. E. Coli concentrations came from feces to prove the increase of E. Coli concentration in the settlement since anthropogenic activities by urban development in Yogyakarta City [15]. Based on collected data E. Coli concentration as an indicator of groundwater pollution, it can be concluded that groundwater in research area has been polluted by E. Coli parameter through $85 \%$ of total samples has exceeded the quality

\section{Conclusion}

The results research assessed the groundwater vulnerability for pollution risk in Yogyakarta City scale, our research identified the seven of each parameters DRASTIC Method by Depth to groundwater (D), Net Recharge (R), Aquifer media (A), Soil media (S), Topography (T), Impact of vadose zone (I), and hydraulic Conductivity $(\mathrm{C})$ from available data, and compiled the datasets into 1: 35.000 scale. We overlay the groundwater vulnerability index with population density parameter to 
assess the groundwater pollution risk potential. The result final assessment that groundwater pollution risk potential are classifies $4,27 \%$ of the area as having very low; $15,12 \%$ of the area as having low, $20,17 \%$ as having moderate, $43,10 \%$ as having high, and $17,34 \%$ as having very high pollution risk potential. The groundwater pollution risk potensial was validated using E. Coli concentration. High value E. Coli concentrations detected in high vulnerable and high pollution risk classes. The model was validated using E. Coli parameters as a represent of pollution risk where the results having exceeds $85 \%$ of total samples that a value exceeds from the standard of quality $>0 \mathrm{MPN} / 100 \mathrm{ml}$. This data inferred the consistency between the calculated vulnerability and groundwater pollution risk.

This research is a preliminary to be continued in the further research and be completed in other publication. The authors gratefully acknowledge funding support of Rekognisi Tugas Akhir Grant.

\section{References}

1. The Central Bureau of Statistics. Kota Yogyakarta in Figure 2018. (2018)

2. P. Sutton. An empirical environmental sustainability index derived solely from nighttime satellite imagery and ecosystem service valuation. J. Popul. Environ. (24), 293-311(2003)

3. I. Ouedraogo, P. Defourny, and M. Vanclooster. Mapping the groundwater vulnerability for pollution at the pan African scale. J. Sci. Total Environ 544, 939-953 (2016)

4. B. M. Evans and L. W Myers. A GIS-based approach to evaluating regional groundwater pollution potential with DRASTIC. J. Soil Water Conserv. 45 (2), 242-245. (1990)

5. L. Yin, E. Zhang, X. Wang, J. Wenninger, J. Dong, L. Guo, and J. Huang. A GIS-based DRASTIC model for assessing groundwater vulnerability in the Ordos Plateau, China. Environ. Earth Sci. 69 (1), 171-185 (2012)

6. L. Aller, T. Bennet, J. H. Leher, R. J. Petty and G. Hackett. DRASTIC: A Standardized System for Evaluating Ground Water Pollution Potential Using Hydrogeological Settings. U.S. Environmental Proctection Agency, Ada Oklahoma 74820, EPA 600/2-87-035, 662 pp. (1987)
7. H. Hendrayana, dan V. A. Vicente. Cadangan air tanah berdasarkan geometri dan konfigurasi sistem akuifer cekungan air tanah Yogyakarta-Sleman. In Prosiding Seminar Nasional Kebumian Ke-6: pp. 356-370 (2013)

8. Sudarmadji. Geographical agitation of unconfined aquifer chemistry in Yogyakarta Municipality Agihan geografi sifat kimiawi air tanah bebas di Kota Madya Yogyakarta. Dissertation. Universitas Gadjah Mada. (1991). In Bahsasa

9. D. P. E. Putra. Evolution of groundwater chemistry on shallow aquifer of Yogyakarta City urban area. Journal of South East Asian Applied Geology. 3 (2), 116-124 (2011)

10. B. Farjad, T. A. Mohamed, N. Wijesekara, S. Pirasteh, and H. Z. B. M Shafri. Groundwater intrinsic vulnerability and risk mapping. In Proceedings of the ICE - Water Management 165 (8), 441-450 (2012)

11. D. P. E., Putra and R. Azzam. Interactions between urban development and groundwater, a case study on Yogyakarta City - Indonesia, In Proceedings of the 16th Conference on Engineering Geology and from Forum Young Engineering Geologist, Bochum., German. (2007)

12. I. S Babiker, A. A. Mohammed, T. Hiyama, and K. Kato. A GIS-based DRASTIC model for assessing aquifer vulnerability in Kakamigahara Heights, Gifu Prefecture, Central Japan. Sci. Total Environ. 345 (1-3), 127-140 (2005)

13. World Health Organization. Guidelines for drinkingwater quality (4th ed.). Geneva: WHO Press (2011)

14. ARGOSS. (2001). Guidelines for assessing the risk to groundwater from on-site sanitation. British Geological Survey Commissioned Report, CR/01/142, 97pp.

15. Putra, D. P. E. The impact of urbanization on groundwater quality; a case study in Yogyakarta City-Indonesia. Dissertation. Mitteilungen zur Ingenieurgeologie und Hydrogeologie, heft Rheinisch-Westfalische Technische Hochschule Aachen. (2007)

16. H. Hendrayana and D. P. E. Putra, Delineation of nitrate contaminant plume in Yogyakarta Urban Area, Yogyakarta, In Proceeding of 29th (IAGI) Association of Indonesian Geologist (2000) 